\title{
Influence of forest growth conditions on the density of wood in the Amur region
}

\author{
Natalia A. Romanova ${ }^{1 *}$, Alexander B. Zhirnov ${ }^{1}$, Natalia A. Yust ${ }^{1}$, Xu Fucheng ${ }^{2}$ \\ ${ }^{1}$ Far-Eastern State Agrarian University, Department of Forestry and Forest Exploitation, Lenin street 180, \\ 675006, Blagoveshchensk, Amur region, Russia \\ ${ }^{2}$ Sino-Russian Forestry Research Center for Plant Cultivation, Xigangzi Beidaying, 164300, Heihe, China
}

\begin{abstract}
In the system of logging machines, a factor such as the density of wood affects all components of the system. However this dependence can be more noticeable in the performance of wood felling, where logging machines have approximately the same saw body, such as a chain saw. In this regard, the problem of determining the dependence of the chainsaw on the density of wood, substantiation of effective options for the number of chainsaws in the assortment and whiplash method of logging is quite relevant. In the Far East of Russia, in particular, in the Amur region, the forest growth conditions are different from the western ones and therefore the properties of the woof differ from the generally accepted ones. The article describes forest growth conditions that influence the properties of the wood in areas of the Amur region. Using the method of density determination, the density of larch, pine and birch were studied first time in the areas of the region. The dependence of the density on humidity, age, species, season of the year and the area of growth was found out. The research results showed that in the Amur region at a humidity of $70 \%$ the density of larch varies from 745 to $1089 \mathrm{~kg} \mathrm{~m}^{-3}$, pine from 435 to $1081 \mathrm{~kg} \mathrm{~m}^{-3}$, birch from 403 to $878 \mathrm{~kg} \mathrm{~m}^{-3}$.
\end{abstract}

Key words: Russian Far East; larch; pine; birch; wood density; wood moisture content

Editor: Vladimír Šebeň

\section{Introduction}

In modern conditions of economics the manufacturing of ecologically safe products, such as products made of wood, is an important theme for entrepreneurs and investors (Wang et al. 2000). While harvesting and processing wood, it is necessary to take into account the following factors: the thickness of trees in the forests in use and the number of trees per unit area; the lay of the land on which the trees in use grow and are subjected to harvesting, soil conditions (type and properties of soil, ground bearing capacity, and so on) and seasons of the year (Grigoriev 2009; Skurikhin \& Korpachev 2004; Kostenko 2012).

It is clear that the density of wood taking into account its different properties, but the density of the wood in the Amur region has been studied first time. The values of the density of wood by the areas of growth were implemented into the work of the customs office of the Amur region dealing with the export of the wood into China.

The Amur region is the region that is rich in woods (Yaborov 2005).The existing practice of their one-sided biomass assessment led to a significant decrease of their potential. The Amur region refers to heavily forested ter- ritories, its forest cover is $64 \%$; the forests on the whole territory are mountainous, more than a half grows on the perpetually frozen ground, others are on the soils with a long-term seasonal frozen ground (Romanova \& Sorvina 2017).

Annual layers affect the chemical composition of cells, and they, in turn, the composition of the soil and climate in the area of larch growth (Earle 2011). The paper (Ugolev 2002) talks about the influence of anthropogenic factor on the thickness of the wood trunk. Data on wood density are published and considered to be generally accepted in Russia. The density of larch at $12 \%$ moisture content is $665 \mathrm{~kg} \mathrm{~m}^{-3}$, pine $505 \mathrm{~kg} \mathrm{~m}^{-3}$ and birch $640 \mathrm{~kg} \mathrm{~m}^{-3}$ (Yaborov 2005). The relative density of pine wood in different forest conditions depends on its anatomical characteristics and is between 0.340 and $0.580 \mathrm{~g} \mathrm{~cm}^{-3}$ (Ugolev 2002). There is a dependence of the wood density and the width of the annual ring on the age of wood (Fries \& Ericsson 2006). The influence of stand density on the growth of trees and qualitative characteristics of wood in plantation pine species in China has been studied (Kang et al. 2004). 
Good proof of the fact that conditions of the forest growth influence the density of the wood. In this work there will be studied the forest growth conditions in the Amur region and first time the values of the density will be found and compared depending on the areas from north ones to southern ones (Stanturf \& Madsen 2004). The main parameters and characteristics of the total forest area will be the forest cover of the territory, species composition, stock, quantity of mature and overmature trees, the characteristic of dominating species (Peltola et al. 2009).

The total stock of wood is assessed to be $1.9 \mathrm{bln} . \mathrm{m}^{3}$ (mature and overmature forest is $50.4 \%$ ), including 1.5 bln. $\mathrm{m}^{3}$ of coniferous species. The total rated wood cutting is $17.7 \%$, including $9.6 \mathrm{mln} . \mathrm{m}^{3}$ of really available forest development (Government of the Amur region). The forest area of the Amur region is $64.4 \%$, the reserve per capita is 19.2 hectares of forests and 1.9 thousand $\mathrm{m}^{3}$ of wood (Yaborov 2005). The forest cover or the ratio of forest land to total land area is found by the ratio of the forest cover area to the total land area and expressed as a percentage. The value of the forest cover in separate areas of the Russian Federation is different and depends on physiographical, climatic and soil conditions. The dynamics of the forest cover is under influence of anthropogenic activities and natural calamities that lead to the forest destruction.

Thus, the aim of the research is to study the influence of forest growth conditions on the density of the wood in the logging areas of the Amur region.

\section{Description of forests in Amur region}

High forest cover in the Far East of Russia is $50-80 \%$, average forest cover is $30-45 \%$; below the average is $10-25 \%$; low is $2-5 \%$.

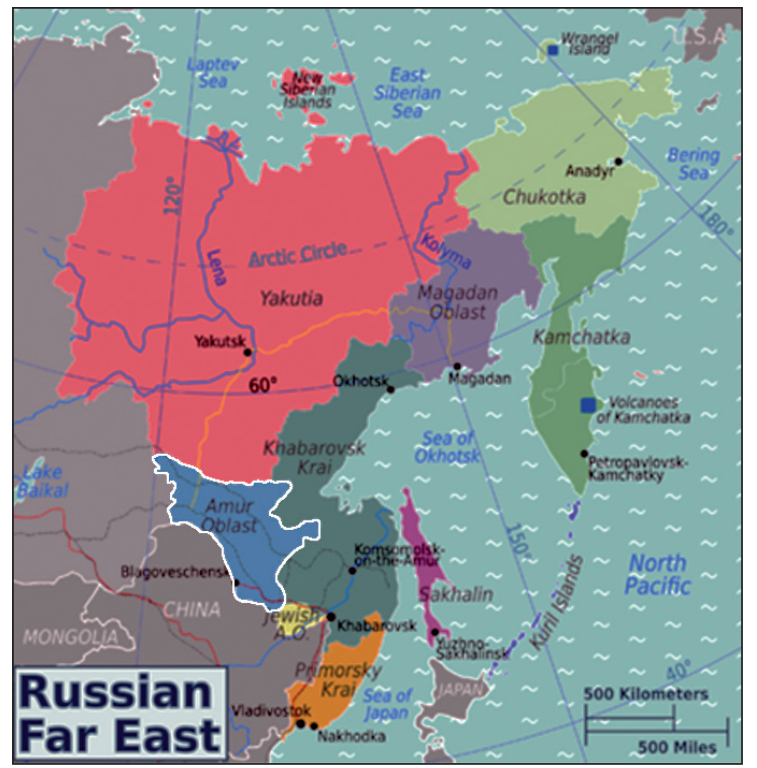

Fig. 1. Map of the Far East of the Russian Federation.

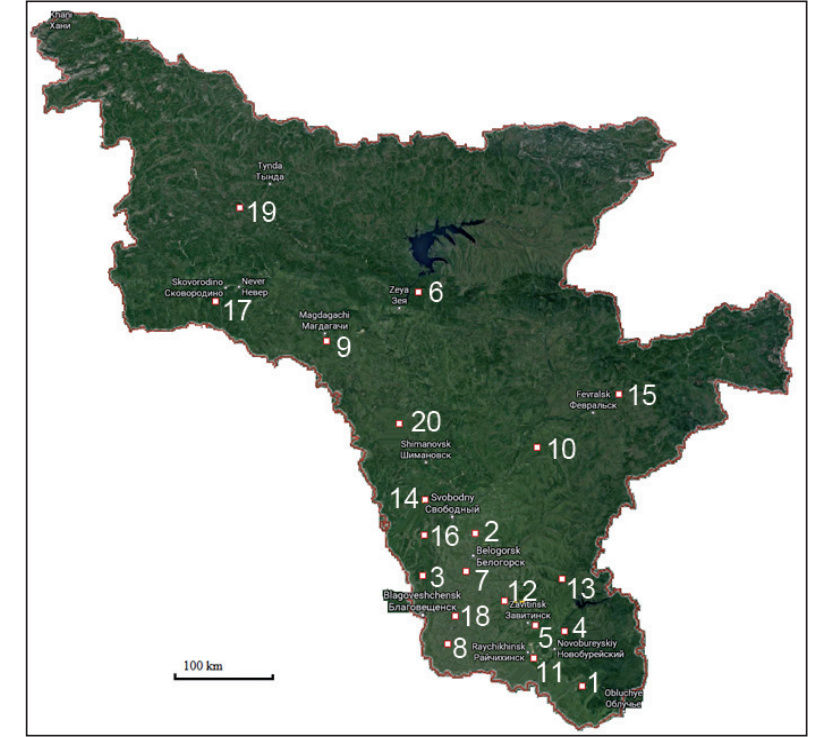

Fig. 2. Map of the Amur region, districts and sampling sites.

Note: 1 - Arkharinsky, 2 - Belogorsky, 3 - Blagoveshchensky, 4 - Bureysky, 5 - Zavitinsky, 6 - Zeysky, 7 - Ivanovsky, 8 - Konstantinovsky, 9 - Magdagachinsky, 10 - Mazanovsky, 11 - Mazanovsky, 12 - Oktyabrsky, 13 - Romnensky, 14 - Svobodnensky, 15 - Selemdzhinsky, 16 - Seryshevsky, 17 - Skovorodinsky, 18 - Tambovsky, 19-Tyndinsky, 20 - Tyndinsky.

At present time the forest cover of the Far-Eastern Federal District is $38.63 \%$, which is the result of the mergence with other far-eastern subjects of the Russian Federation with forest cover from 7 till $76 \%$ (Kostenko 2012).

Taking into account the forested lands of State Forest Fund, the forest cover of the Amur region is $64.4 \%$. The forest cover changes from north-west to the south of the region from $74 \%$ till less than $0.3 \%$ (Fig. 1,2 ). Some administrative areas or $78 \%$ of its total area are richly wooded (Yaborov 2005).

For the Far East there was found an optimal forest cover at the level of $50-55 \%$, at which the forests fulfill all their functions. In such areas as Tambovsky, Belogorsky, Ivanovsky, Konstantinovsky, Mikhailovsky, Seryshevsky, Oktyabrsky, Zavitinsky, Blagoveshchensky, Svobodnensky, Romnensky, Bureysky the forest cover volatiles between 10 and 50\% (Romanova \& Sorvina 2017).

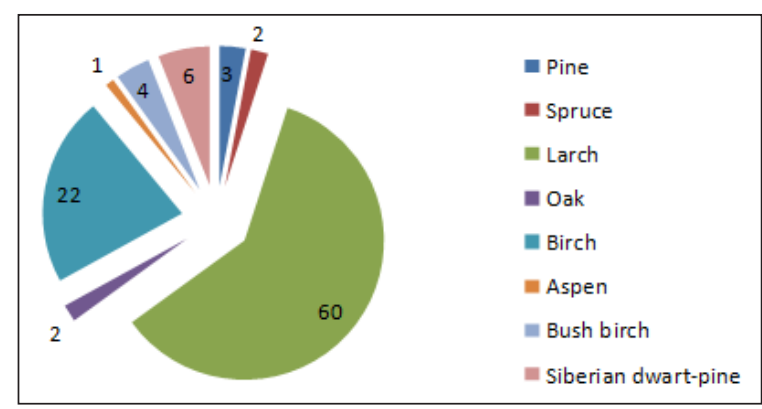

Fig. 3. Forest area by the predominant species in the Amur region. 
Table 1. The forest cover of administrative areas.

\begin{tabular}{|c|c|c|}
\hline Administrative district & $\begin{array}{l}\text { The land area of the forest } \\
\text { fund, [thous. ha] }\end{array}$ & $\begin{array}{c}\text { Forest cover } \\
{[\%]}\end{array}$ \\
\hline Arkharinsky & 1107.5 & 55 \\
\hline Belogorsky & 4.8 & 0.9 \\
\hline Blagoveshchensky & 135.9 & 37.0 \\
\hline Bureysky & 411.9 & 46.7 \\
\hline Zavitinsky & 135.2 & 22.0 \\
\hline Zeysky & 8489.2 & 74.0 \\
\hline Ivanovsky & 2.0 & 0.6 \\
\hline Konstantinovsky & 1.7 & 0.6 \\
\hline Magdagachinsky & 1402.1 & 74.0 \\
\hline Mazanovsky & 2474.7 & 54.5 \\
\hline Mikhailovsky & 5.8 & 2.0 \\
\hline Oktyabrsky & 33.0 & 11.0 \\
\hline Romnensky & 801.4 & 52.0 \\
\hline Svobodnensky & 514.0 & 45.0 \\
\hline Selemdzhinsky & 4435,5 & 74.0 \\
\hline Seryshevsky & 57.6 & 10.0 \\
\hline Skovorodinsky & 1828.9 & 74.0 \\
\hline Tambovsky & 1.5 & 0.3 \\
\hline Tyndinsky & 8331.5 & 70.0 \\
\hline Shimanovsky & 1284.9 & 69.0 \\
\hline The Amur region & 31459.1 & Average: \\
\hline
\end{tabular}

For experimental studies there were taken the species of the wood from those regions where the assessment of the forest cover was higher (Table 1). By this criterion the following areas were chosen:Zeysky, Skovorodinsky, Magdagachinsky, Selemdzhinsky, Shimanovsky. With average forest cover there were chosen Svobodnensky and Bureysky areas. The average forest cover in these areas was 38.63\% (Yaborov 2005). The height above sea level is $300-400 \mathrm{~m}$, and in the North of the region up to $1000-1200 \mathrm{~m}$.

Main forest forming species are larch, birch, spruce, and pine. About $70 \%$ of the area is covered with coniferous species. Soft-wooded broadleaved species take 2.7 times less space than coniferous species; hard-wooded broadleaved species take $2.4 \%$ of land covered with forests and they are mainly in Zeysko-Bureysky, Belogorsky and Tygdinsky forest areas.

The diversity of the wood species is presented by 20 species, among which 10 species predominate. Coniferous species take $65.1 \%$ of the forest cover, hard-wooded broadleaved species take $2.2 \%$, soft-wooded broadleaved species take $23.0 \%$, and bushes take $9.7 \%$. Main forest forming species are presented in the Fig. 3.

Among coniferous species the biggest area is taken by the Dahurian larch (60\%), including $80 \%$ of the area in the northern parts, $50-60 \%$ in western parts, from $12 \%$ till $35 \%$ in central and eastern parts. In raw stock the larch makes $72.1 \%$. The most valuable cedar forests grow in Arkharinsky area and make $0.3 \%$ of the forest cover. The cedar is forbidden for cutting and it is protected.

The raw stock value of pines and spruces is lower than their ecological and social value and intensiveness of their cutting is reducing. The area of pines as the most cut down in the region is $3.2 \%$ of the forest cover and is in need of protection and reduction of cutting. The pine forests are mostly concentrated to the west of the Selemdzha river. To the east of this border pines can be found in small parts near rivers the Byssa, the Tom' and the Arkhara. The area of the young stock for the last 30 years has increased by $16 \%$ and the area and stock of mature trees has decreased 2.5 times.

In the age structure of the forest fund mature and overmature forests predominate (34.2\%), middle-aged forests and young forests take the biggest part of the area: $31.8 \%$ and $23.4 \%$, respectively. The formation of the young forest is conditioned by forest fires and cuttings. The decrease of the area with mature and overmature forests is caused by cuttings. To provide the continuous use of timber in the region, the proportion of mature, overmature and maturing forests must be at the level of 10 - 15\% (Yaborov 2005; Romanova 2017).

In the experimental studies there were involved those species of trees which have a high percentage of the timber stand in the region. Among the coniferous species there is Dahurian larch, the Scots pine and among the broad-leaved trees there is the Asian.

Dahurian larch(Larix gmelini (Rupr.) Rupr.) is a unique tree that grows in almost all forms of the land form and it grows in the mountains till $2-2.5$ thous. meters. Pure forest stand is formed only in the conditions unfavourable for other species: swamps, frozen grounds and steep hills. In all other types of soil it grows together with pine, spruce and birch. The tree of the first size grows till 35 meters of height and 1.5 meters in a diameter. The body of the tree is straight, tapered and usually it is longbutt. The bark is light-grey, while young it is thin pellety, while old it is thick, reddish and fissured. It lives up to 500 years old and more. The tree crown is cone-shaped or pyramidal, crumby. The needle foliage is light green, soft, short; 20 - 60 needles in the bunch drop annually. The network of roots is deep in freshly drained soils and overground in swamped and frozen ones.

Fresh wood of the larch has the moisture of $82 \%$. The maximal moisture at water absorbability is $126 \%$. As with any other tree species the growing larch has seasonal and day fluctuations in moisture which under the common pattern are revealed to a lesser degree.

The average value of the density of the larch wood under standard humidity (12\%) is $665 \mathrm{~kg} \mathrm{~m}^{-3}$, at dry conditions it is $635 \mathrm{~kg} \mathrm{~m}^{-3}$, the average basic density is $540 \mathrm{~kg} \mathrm{~m}^{-3}$. The density of the larch wood strongly depends on the type and place of growth. The larch lumber that has the highest density wood grows in Altai $\left(725 \mathrm{~kg} \mathrm{~m}^{-3}\right)$, in Ural and Cis-Ural areas $\left(675 \mathrm{~kg} \mathrm{~m}^{-3}\right)$. The least density wood is typical for the European larch $\left(506 \mathrm{~kg} \mathrm{~m}^{-3}\right.$ ) (Yaborov 2005; Earle 2011; Besschetnov et al. 2018).

The larch wood is hard, heavy and very tough. The specific gravity of air-dried wood is $0.7-0.76$, of fresh one is $0.9-1.0$, it sinks in water. It is used in building and furniture manufacturing, especially in those situations where the toughness and durability are necessary in a damp and humid surrounding. It is used for making low timber sets of buildings, mine log-houses, utility poles, piles and bridges. The firewoods have high calorific effect. The bark is used as tanning bark while currying 
and dying. The larch resin is used at making valuable varnishes and glues. The medications made from the bark, young shoots and needles are used in medicine (Yaborov 2005).

The Scots pine (Pinus sylvestris L.). This species is one of the most wide-spread species that grow in the Amur region. It takes 487.5 thous. ha, and it grows in Tygdinsky, Tyndinsky and Zeysky forest areas. It grows in different types of land area: from flood beds of rivers till mountain peaks. It forms pure forest stands predominantly in mountainous conditions on sandy soils. In flood beds of rivers in argilloarenaceous grounds it grows together with the spruce, aspen, silver-fir; on the plains it grows in combination with the larch, birch, oak and other wood species.

The tree is big: till 40 meters in height and 1.5 meters in a diameter and it lives up to 580 years old. The body is slim, straight with a high crown. The bark in the low part is reddish-brown, thick; in the upper part it is yellowishorange, thin and smooth. The network of roots is rachidian in rich soils, and overground in sphagnous swamps. The needles are semi circled, paired, tough and green.

The pine is a typical species for sandy soils. It is hardy to soils, does not tolerate salty soils and a lot of water. It is light-demanding and cold enduring. It can suffer from air pollution. The pine that grows in the northern part of Russia, namely, Angarskaya, Karelskaya, Arkhangelskaya, are the best materials for building which have outstanding physical-mechanical properties.

Technical characteristics of the pine: density is $513 \mathrm{~kg} \mathrm{~m}^{-3}$, density in the fresh wood is $625 \mathrm{~kg} \mathrm{~m}^{-3}$, specific gravity is 0.51 ; ultimate static bending strength of wood is $71.8 \mathrm{Mpa}$, compressive strength along the grain of wood is $34.8 \mathrm{Mpa}$, ultimate tensile strength along the grain of wood is $84.1 \mathrm{Mpa}$ (data taken at humidity of $12 \%$; $1 \mathrm{MPa}=1 \mathrm{n}$ per $\mathrm{mm}^{2}$ ) (Wang et al. 2000; Andersone \& Ievinsh 2002; Fries \& Ericsson 2006; Kozlov et al. 2009; Peltola et al. 2009; Romanova 2017).

Asian white birch (Betula platyphylla Sukacz) grows in all soils, survives in excessive soil water and grows well in dry soils of mountain slopes. In poor soils it forms almost pure stands, in most cases of secondary origin. In relatively rich soils there are mixed forests of spruce, pine, oak, aspen, etc.

In good soils it reaches up to $27 \mathrm{~m}$ in height and up to $60 \mathrm{~cm}$ in diameter. It lives to 150 years old, sometimes up to 250 years old. The trunk is straight with a wide, spreading and loose crown. The shoots bark is smooth dark, the bark of branches and of the top of the trunk is white (birch bark). At the bottom of the trunk the bark gets dark, almost black and fissured when the tree gets older. The leaves are light green, the root system is shallow.

Properties of birch wood: the density is $0.63 \mathrm{~g} \mathrm{~cm}^{-3}$, the mechanical hardness is $40-48 \mathrm{MPa}$, flexural strength is $80-90 \mathrm{MPa}$, the compressive strength is $45-55 \mathrm{MPa}$, impact strength is $70-80 \mathrm{~J} \mathrm{~m}^{-2}$, the wear by abrasion is 0.5 - 0.6 mm (Givnish 2002; Yaborov 2005; Moser et al. 2015; Dyachuk 2018).

The forest-growing conditions of wood include the climate of the region with sunlight, average air temperature, precipitation, air humidity, wind speed and soil composition. The temperature and light conditions and water availability necessary for the development of plants and limiting their geographical distribution depend on the climate.

The Amur region is part of the Far-eastern region of the Russian Federation. The territory of the Amur region belongs to the continental transition group of ecosystems with a monsoon climate. This group is influenced by the seas and oceans only in the warm period of theyear unlike other groups of the Far East.

The coldest areas of the Amur region are Tyndinsky, Skovorodinsky (north-west of the region) and Selemdzhinsky (east of the region). Selemdzhinsky area is located in a mountain range, in the valley of the river Selemdzha. It is surrounded on three sides by Selemdzhinsky ridge, Yam-Alin and Turan ranges, and here, as a result, chilly and heavier air masses flow, which makes winter temperatures low and annual average temperature sub-zero. The warmest place in the region is the southwest adjacent to the Amur river. This area includes Blagoveshchensk and Poyarkovo.

Winter is the longest season of the year in the Amur region; it lasts from late October to late March or early April. The winter has frosty, low wind weather with little rainfall which results in the low snow cover, low absolute humidity and high relative humidity. In the cold season, the weather is clear: the Amur region takes one of the first places in Russia by the number of sunshine hours in the winter (Yaborov 2005).

In the spring in the Amur region dry winds are often observed. Often dry winds are accompanied by dust or sand storms.

Table 2. Climate in the Amur region.

\begin{tabular}{|c|c|c|c|c|c|c|}
\hline \multirow[t]{2}{*}{ Districts } & \multicolumn{2}{|c|}{ Air temperature, average $\left[{ }^{\circ} \mathrm{C}\right]$} & \multirow{2}{*}{$\begin{array}{c}\text { Precipitation } \\
\text { [mm] } \\
\text { year }\end{array}$} & \multirow{2}{*}{$\begin{array}{c}\text { Humidity } \\
{[\%]} \\
\text { year }\end{array}$} & \multirow{2}{*}{$\begin{array}{c}\text { Wind speed } \\
{\left[\mathrm{m} \mathrm{sec}^{-1}\right]} \\
\text { year }\end{array}$} & \multirow[t]{2}{*}{ Soils } \\
\hline & January & July & & & & \\
\hline Tyndinsky & -32.8 & 17.6 & 456 & 70 & 1.6 & Mountain-brown-taiga and mountain-tundra \\
\hline zeysky & -32.5 & 17.8 & 580 & 72 & 1.6 & Mountain-tundra, mountain-brown-taiga and marsh \\
\hline skovorodinsky & -29.1 & 18 & 482 & 71 & 2.3 & Mountain-brown-taiga \\
\hline magdagachinsky & -30.1 & 18.6 & 530 & 69 & 2 & Brown-taiga and marsh \\
\hline Selemdzhinsky & -33.1 & 16.8 & 728 & 74 & 1.2 & Brown forest, mountain-brown-taiga \\
\hline shimanovsky & -29.4 & 20.8 & 611 & 71 & 2 & Brown-taiga and marsh \\
\hline Svobodnensky & -24.3 & 24.3 & 575 & 69 & 2.4 & Brown-taiga \\
\hline bureysky & -26.7 & 26.7 & 685 & 73 & 3.3 & Brown-taiga and meadow \\
\hline
\end{tabular}




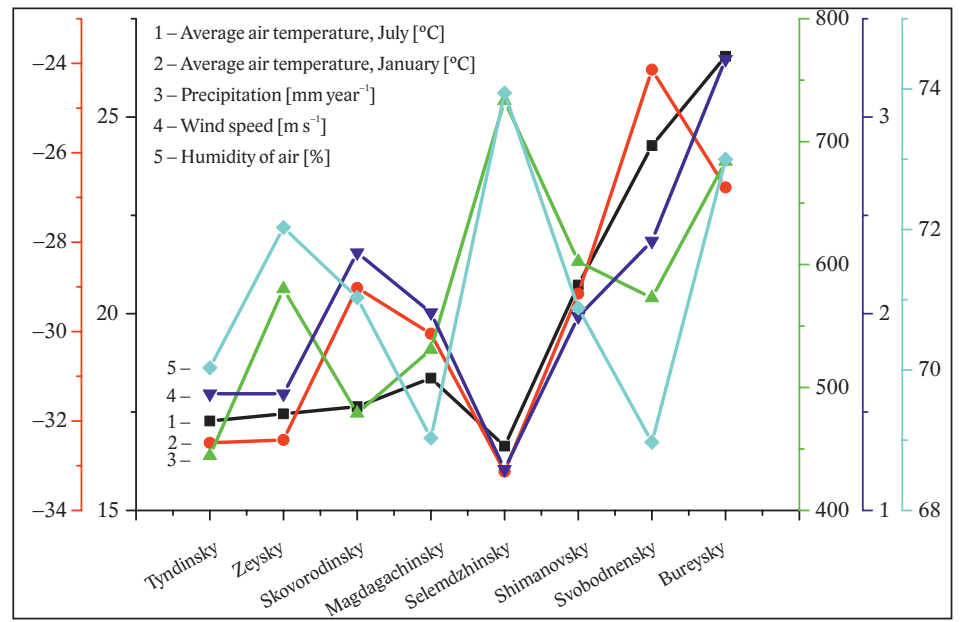

Fig. 4. Climate features in the Amur region.

Summer comes in late May or early June. Summer is moderately hot, in the north it is warm with high clouds and significant rainfall. The first half of the summer is usually warm and sunny, and sometimes too dry. And the second half of the summer is often excessively wet. Intense torrential rains often cause floods in the rivers. The rainiest months of the year for the whole region are July and August: $40-50 \%$ of annual precipitation falls during these two months.

Amur autumn is the shortest season of the year. In the north of the Amur region it begins in mid-August, in the South in the first days of September. The period with average daily temperatures below $+15^{\circ} \mathrm{C}$, but above zero, lasts an average of $40-45$ days. In the first half of October in the north of the region the average daily temperature drops to sub-zero, in the south it occurs at the end of October, and this means the beginning of winter.

The second ten-day period of September is the average date of the first autumn frosts. Once every $3-4$ years early frosts in early September destroy the crop. This causes a huge damage to the agriculture of the region.

The first snow in the north of the region falls in September, in the south in the first half of October, but sometimes, the first snowflakes can be seen in the second ten days of September even in the south.

The conditions for soil formation in the Amur region are characterized by a number of features: 1 ) cold, snowfree winter contributes to deep freezing of the soil; 2 ) cold, dry, prolonged spring slows down the thawing of the soil and the development of plants; 3) warm and rainy summer (in July and August, half of the annual rainfall falls) leads to waterlogging.

Meadow black soils develop on brown clays of river and lake origin, under meadow and meadow-marsh grassy vegetation. They are characterized by high fertility, the humus horizon is 20 to $40 \mathrm{~cm}$ and sometimes 50 $\mathrm{cm}$. The humus content in the top is 4 to $8 \%$. By colour, structure and fertility they resemble the black soil of the European part of Russia. Therefore, the first researchers of the nature of the Amur region and immigrants called them "Amur black soils" (Yaborov 2005). In the areas where the forest cover is the highest, brown-taiga and mountain-brown-taiga soils prevail (see Table. 2). These soils are most favorable for the growth of larch and pine.

Thus, the richer the soil is, the more nutrients the wood gets, it becomes looser, the annual rings become wider, and accordingly its density and weight get less. But logging companies seek to treat the wood which in a small volume will be heavier. Therefore, the worse the soil of wood growth is, the more profitable it is for loggers.

The purpose of the paper is to study the density of wood in the Amur region.

Objectives: 1 . To study and analyze the climate of the Amur Region by regions. 2. To study the dependence of the density of wood on the area of growth and other factors.

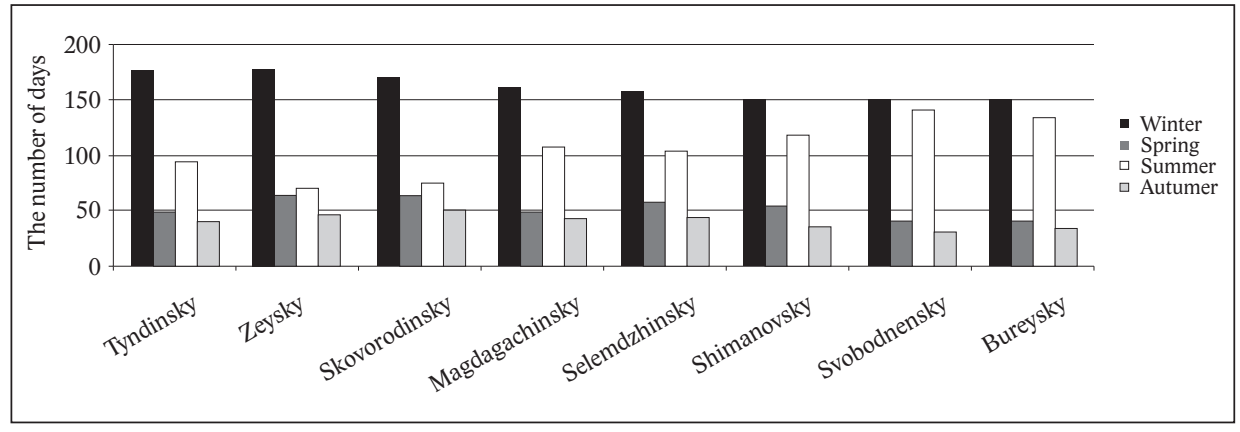

Fig. 5. Duration of seasons of the year in days by districts. 


\section{Method}

For research of density of wood of plantings the experimental material prepare according to GOST 16483.6-80 providing rules of the choice of model trees on these areas and cutting of model trees on ranges. Four samples from each of the 50 trees in each study area were selected for the experiment. 1600 samples of each wood species, a total of 4800 pieces. The age of the tree was determined by annual rings when harvesting it directly on the cutting area. The age of these trees ranged from 65 to 110 years. Sites on which logging enterprises of the Amur region conduct harvesting of wood annually. In different climatic conditions and in the mountains and in the lowland, on marshy soils and in very windy places. The location of the trees is varied, both in the lowlands and swamps, and in the mountainous areas. Accordingly, the trees grew in different climatic conditions (different humidity, the number of light days, soil, etc.). Growing trees cut down and determined their age and moisture with tree rings and electrolaser. From the lump (stump) part of the wood samples of $20 \times 20 \times 20 \mathrm{~mm}$ were cut out in the number of 4 pieces from each tree.

The density of wood is characterized by the ratio of its mass to volume. Density is measured in kilograms per cubic meter or grams per cubic centimeter.

In laboratory conditions, the density of wood is determined on samples of rectangular cross-section of $20 \times$ $20 \mathrm{~mm}$ in size and height (along the length of the fibers) of $30 \mathrm{~mm}$ (all-Union State Standard 16483.1-84). The mass is determined by weighing on an electronic scale with an error of up to $0.01 \mathrm{~g}$, the linear dimensions by a calliper of accuracy class 2, an error of up to $0.01 \mathrm{~mm}$ (GOST (all-Union State Standard) 2005; Romanova \& Baranov 2016; Romanova 2017).

Determine the conditional density as follows: the sample is kept in distilled water for about 3 days, until it acquires a constant size and determine its volume $V_{\max }$ in multiplying the sides of the sample measured with a caliper. The sample is then dried for about 8 hours in a drying Cabinet at $112^{\circ} \mathrm{C}$ to a dry state and the mass $m_{0}$ is determined by weighing. The formula is used to calculate the conditional density:

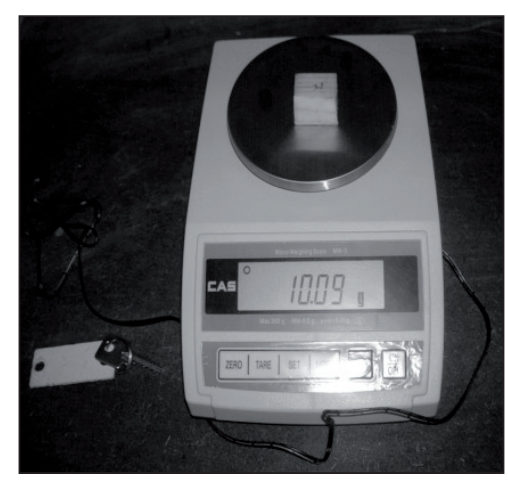

Fig. 6. Electronic laboratory scale MWII-200B.

$$
\rho=m_{0} / V_{\max }
$$

where $m_{0}$ - the mass of the wood sample in a completely dry state, $\mathrm{kg} ; V_{\max }$ - the volume of the sample at humidity above the hygroscopicity limit, $\mathrm{m}^{3}$.

The density of wood at humidity above the limit of hygroscopicity ( $W=70 \%$ ) was determined by the following formula:

$$
P_{w 1}=P_{12}(1+0.01 W 1) / 1.206
$$

$W_{1}$ - moisture content of wood, \%;

$P_{12}$ - wood density at $12 \%$ humidity.

The volume is calculated as a product of the results of measurements of width, thickness, and height and expressed in fractions of cubic meter $\left(\mathrm{m}^{3}\right)$. In addition, the volume can be measured by the device - a volume meter by the sample displaced liquid (mercury) not wetting the wood. The sample may have an irregular geometric shape.

The density of wood depends on the humidity and to compare, the density values are always made by single humidity. The density, as well as all the other indicators of physical and mechanical properties of wood, should be reduced to a standard humidity of $12 \%$ ( $\rho 12 \%)$.

For calculations, the density of wood is sometimes used in a completely dry state: in this case, the weight and volume of wood are measured after the sample is dried to a moisture content of zero.

For some purposes, it is convenient to use a value called the conditional density of wood. This indicator is calculated as the ratio of the sample mass in a completely dry state to the sample volume at the hygroscopicity limit $\left(W_{h . l}=30 \%\right)$. The relative density of wood does not depend on moisture.

The conditional density is determined as follows: the sample is kept in water until it acquires a constant size and then its volume $V_{\max }$ is found. The sample is then dried to a dry state and the $m_{0}$ mass is determined by weighing. By dividing the mass by the volume of the sample, the conditional density is calculated.

With increasing moisture content, the wood density increases. Within the annual layer the density of wood is different: the density of late wood is $2-3$ times greater than the early one. Therefore, the better developed the

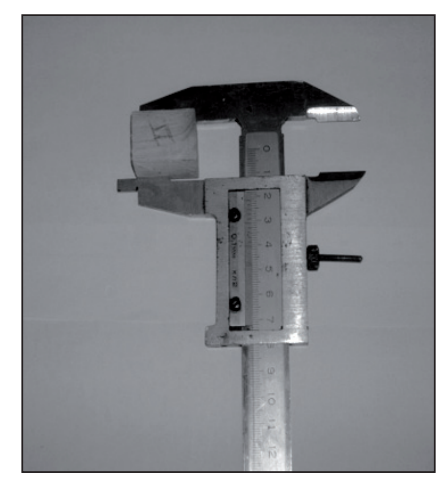

Fig. 7. A calliper, accuracy class 2. 
late wood is, the higher its density becomes. Heavier wood is more durable. Density is the amount of wood substance in unit volume. The amount of wood substance is directly dependent on the size of the anatomical elements that perform a mechanical function in a living tree.

By the density at humidity of $12 \%$, the wood species can be divided into three groups: species with small $\left(540 \mathrm{~kg} \mathrm{~m}^{-3}\right.$ or less), medium $\left(550-740 \mathrm{~kg} \mathrm{~m}^{-3}\right)$ and high (750 $\mathrm{kg} \mathrm{m}^{-3}$ and above) density.

\section{Results and discussion}

According to All Union State Standard 6483.1-84, experimental studies were conducted on the density of wood of different species growing in the Amur region at normalized humidity. According to the experimental data, diagrams of the wood density dependence on various forest growth factors were made. The studies were conducted in different seasons: winter and summer (GOST (all-Union State Standard) 2005; Romanova \& Sorvina 2017; Dyachuk 2018).

In the process of experimental studies, samples were taken from the butt part of the wood. Three types of wood: Daurian larch, pine and Asian white birch were under study. Forest areas of the Amur region became the places of research where the sampling was carried out. The number of samples of 10 for each species of wood from each district of the region, the trees corresponded to the 5 th class of age.

Experimental studies have identified the main factors affecting the density of wood: the area of growth, the season (winter, summer), species, age and wood moisture. After analyzing the data using Excel software and building a chart, the dependence of the density of wood on various factors was found out.

Having studied the dependence of density on moisture (through the example of larch, pine and birch growing in Tynda area, Fig. 7), it was concluded that the higher the moisture content of the wood was, the greater its density became. So at humidity of $20 \%$ the density of larch was $777.85 \mathrm{~kg} \mathrm{~m}^{-3}$, of pine it was $688.12 \mathrm{~kg} \mathrm{~m}^{-3}$, of birch it was 519.11 ; at humidity of $70 \%$ the density of larch was $1088.99 \mathrm{~kg} \mathrm{~m}^{-3}$, of pine it was $919.8 \mathrm{~kg} \mathrm{~m}^{-3}$, of birch it was $915.9 \mathrm{~kg} \mathrm{~m}^{-3}$; when the humidity was $120 \%$, the density of larch was $1404.97 \mathrm{~kg} \mathrm{~m}^{-3}$, of pine $1186.69 \mathrm{~kg} \mathrm{~m}^{-3}$, of birch 1181.66 (Ugolev 2002; Romanova \& Baranov 2016).

Table 3. Statistics based on the wood density $\left[\mathrm{kg} \mathrm{m}^{-3}\right]$ from moisture.

\begin{tabular}{lcc}
\hline Variable & Median & Standard deviation \\
\hline Density of larch & 831 & 190 \\
Density of pine & 641 & 51 \\
Density of birch & 692 & 139 \\
\hline
\end{tabular}

Analyzing Figure 8, it can be concluded that the wood species influences its density. Larch wood had the most density, birch had the least among the studied. Pine is the species that have an average density, though its density is slightly greater than that of birch.

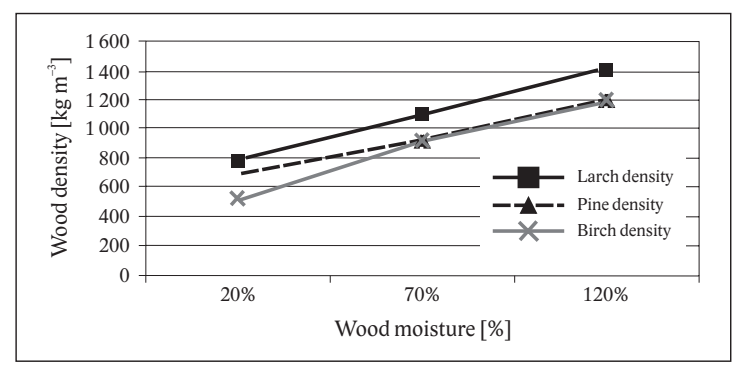

Fig. 8. Dependence of wood density on moisture (Tyndinsky district).

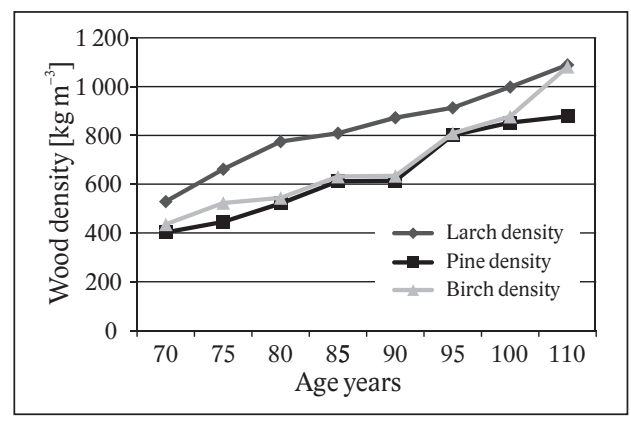

Fig. 9. Dependence of density on the age of wood of different species growing in Tyndinsky districts of the Amur region.

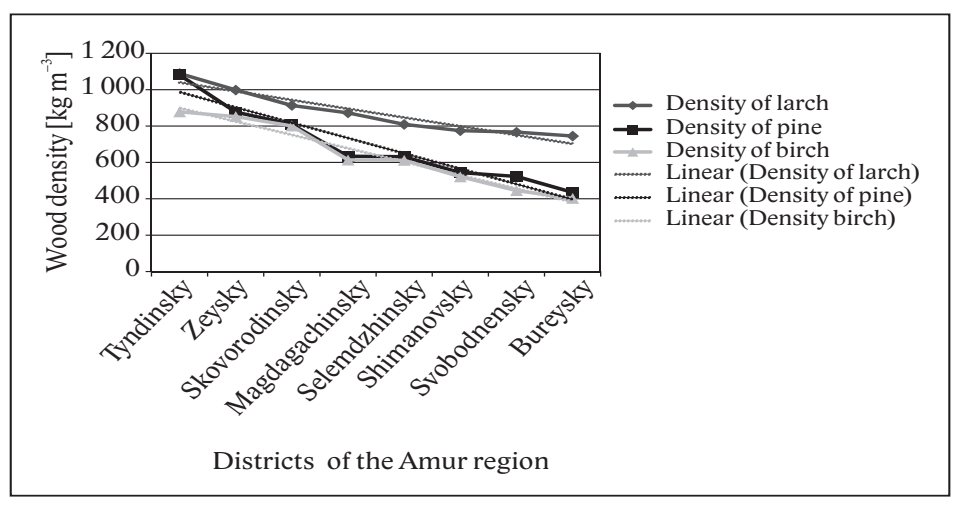

Fig. 10. Wood density dependence on the districts of the Amur region. 
Having studied the dependence of the density of wood on age and species (through the example of Tyndinsky area, Fig. 8), it was found out that that the older the tree was, the greater its density was. The density of larch that has grown to 110 years old is $1089 \mathrm{~kg} \mathrm{~m}^{-3}$ at average humidity, which is 210 times more than the density of larch that is 65 years old. The corresponding dependence was obtained in other areas of the region (Kostenko 2012; Romanova \& Baranov 2016; Romanova 2017; Dyachuk 2018).

Table 4. Statistics are based on data on the wood density $\left[\mathrm{kg} \mathrm{m}^{-3}\right]$ and age of the wood.

\begin{tabular}{lc}
\hline Variable & Standard deviation \\
\hline Density of larch & 180 \\
Density of pine & 184 \\
Density of birch & 215 \\
\hline
\end{tabular}

Having studied the dependence of the density of wood on the area of growth, (Fig. 10), it was found out that the further to the north the area is located, the more density the wood has. Using the trend line, the linear dependence equations were made. For larch the equation is $y$ $=-72.44 \mathrm{x}+1156.9$, the coefficient of determination is 0.97 . For birch the equation is $y=-84.375 x+1071.5$, the coefficient of determination is 0.92 . For pine the equation is $y=-73.878 x+973.09$, the coefficient of determination is 0.96 . The coefficient of determination is close to one, which indicates a direct relationship between the density of wood and the area of its growth.

Having studied the dependence of the density of wood on the time of year, it was found out that the same species of wood of the same age growing in the same area have greater density in winter than in summer. Larch growing in Tyndinsky area has the density of $1088.99 \mathrm{~kg} \mathrm{~m}^{-3}$ in winter and $968.99 \mathrm{~kg} \mathrm{~m}^{-3}$ in summer. Thus, the density of wood depends on the species, humidity, age, the climate of the environment, i.e. the area of growth, and the time of year.

Table 5. The maximum density of wood $\left[\mathrm{kg} \mathrm{m}^{-3}\right]$ in the Amur region.

\begin{tabular}{lccc}
\hline Districts & Density of larch & Density of pine & Density of birch \\
\hline Tyndinsky & 1088.99 & 1081.28 & 878.23 \\
Zeysky & 998.26 & 877.06 & 852.33 \\
Skovorodinsky & 913.25 & 808.45 & 800.6 \\
Magdagachinsky & 872.62 & 633.95 & 613.5 \\
Selemdzhinsky & 809.11 & 631.28 & 611.6 \\
Shimanovsky & 774.54 & 543.9 & 521.06 \\
Svobodnensky & 766.28 & 522.93 & 445.21 \\
Bureysky & 745.26 & 435.49 & 402.57 \\
\hline Average & 871.04 & 691.79 & 640.64 \\
\hline
\end{tabular}

Experimental studies have shown that in each area of growth of wood, under different forest conditions, the density of the same wood is different, and it does not meet the generally accepted standards and differs a lot from the north to the south.

In a variety of reference books the density of such species as birch, pine and larch is taken to be 890,720 , $930 \mathrm{~kg} \mathrm{~m}^{-3}$, respectively, at humidity of $70 \%$ (Ugolev
2002; Tyukavina 2017). In our studies, these values range from 402 to $1088 \mathrm{~kg} \mathrm{~m}^{-3}$ (see Table 4). In each area, the density of wood has its own values, which allows to choose the logging equipment that is different in capacity and cost.

Table 6. Main statistical indicators for wood density $\left[\mathrm{kg} \mathrm{m}^{-3}\right]$.

\begin{tabular}{lcc}
\hline Variable & Median & Standard deviation \\
\hline Density of larch & 841 & 123 \\
Density of pine & 633 & 215 \\
Density of birch & 613 & 184 \\
\hline
\end{tabular}

According to experimental data, the dependence equations and the validity coefficient are made: for larch it is $y=-48.162 x+1087.8, R^{2}=0.9242$; for pine it is $\mathrm{y}=-84.375 \mathrm{x}+1071.5, \mathrm{R}^{2}=0.9242$; for birch it is $y=-73.878 x+973.09, R^{2}=0.9648$. The validity coefficient is close to 1 , which indicates a high convergence of the results (Zaki \& Meira 2014; Romanova \& Baranov 2016).

Density of wood depends on many factors, including forest growth (Ugolev 2002). Each breed has different density (Kang et al. 2004). Larch has $415-635 \mathrm{~kg} \mathrm{~m}^{-3}$ (Fries \& Ericsson 2006; Earle 2011), pine has 415 $505 \mathrm{~kg} \mathrm{~m}^{-3}$ (Wang et al. 2000; Andersone \& Ievinsh 2002; Fries A., Ericsson 2006; Peltola et al. 2009), birch has 520 -640 kg m³ (Kostenko 2012; Romanova 2017; Dyachuk 2018). In the Northern subzone of the taiga conditional density of pine wood is $0.340-0.580 \mathrm{~g} \mathrm{~cm}^{-3}$ (Tyukavina et al. 2017).

Experimental studies have found that in each area of wood growth, respectively, under different forest conditions, the density of the same wood is different, and it does not meet the generally accepted standards and has a large run from the North to the South.

In our study, the densities of the larch range from 745 to $1088 \mathrm{~kg} \mathrm{~m}^{-3}$, the density of pine from 435 to $1081 \mathrm{~kg} \mathrm{~m}^{-3}$, the density of birch from 402 to $878 \mathrm{~kg} \mathrm{~m}^{-3}$. In each district the density of wood has its own values, which allows us to select the logging equipment of different capacities and cost. The object of research is the forest plantations of the Amur region. The initial data for the statistical analysis are the data of 8 districts of the region and the database consisting of the taxation characteristics of forest plantations. Using the module "classification and regression trees" in the STATISTICA environment, the cluster analysis of the main forest growth factors affecting the density was carried out (Stanturf \& Madsen 2004; Zaki \& Meira 2014; Moser et al. 2015).

\section{Conclusion}

The impact of forest growth conditions on the density of wood in the Amur region was studied for the first time. The fundamental factors affecting the density of wood are the length of the seasons, air temperature, precipitation, wind speed, humidity, type of soil on which a certain species of wood grows. 
The climate of the region varies from north to south. Winter is the longest season of the year; in the northern areas it lasts 178 days, in the southern ones 154 days. The minimum air temperatures in the southern areas of the Amur region range from $-40^{\circ}$ to $-45^{\circ} \mathrm{C}$, in the northern ones from $-50^{\circ} \mathrm{C}$ to $-55^{\circ} \mathrm{C}$. Depending on the duration of the seasons of the year, the northern and southern areas of the Amur region were identified. Tyndinsky, Zeysky, Skovorodinsky, Magdagachinsky, Selemdzhinsky areas are northern areas of the Amur region, and Shimanovsky, Svobodnensky, Bureysky are southern ones. In areas where the forest area is the highest, brown-taiga and mountain brown-taiga soils prevail. Among coniferous species, the largest area is occupied by Dahurian larch (59.8\%). In northern areas it takes up to $80 \%$ of the area, in the southern ones $50-60 \%$. Considering raw stocks, larch takes $72.1 \%$, pine $2.7 \%$, birch $15.9 \%$.

Studies of the effect of forest growth conditions on the density of wood in the Amur region have shown that the further to the north the area of wood growth is, the greater its density becomes. The density of wood was found out for the first time. The density of larch at humidity $70 \%$ is from $530 \mathrm{~kg} \mathrm{~m}^{-3}$ in the southern areas to $1089 \mathrm{~kg} \mathrm{~m}^{-3}$ in northern areas, the density of pine is from $435 \mathrm{~kg} \mathrm{~m}^{-3}$ to $1002 \mathrm{~kg} \mathrm{~m}^{-3}$, the density of birch is from $400 \mathrm{~kg} \mathrm{~m}^{-3}$ to $830 \mathrm{~kg} / \mathrm{m}^{3}$.

Thus, based on the experimental studies, we recommend that to determine the volume (mass) of wood (for example, for export abroad of the Russian Federation through customs) use not the average density, but the density that corresponds to the area of growth.

\section{References}

Andersone, U., Ievinsh, G., 2002: Changes of Morphogenic Competence in Mature Pinus sylvestris L. Buds in vitro. Annals of Botany, 90:293-298.

Besschetnov, V. P., Besschetnova, N. N., Esichev, A.O., 2018: Evaluation of the physiological status of larch trees (Larix Mill.) in the conditions of Nizhny Novgorod region. Lesn. Journ. Bulletin of higher educational institutions, 1:9-17.

Dyachuk, E. V., 2018: Influence of growth conditions on the properties of birch in Zavetinsky area of the Amur region. Youth of the XXI century: a step into the future. Materials of XIX Regional scientific and practical conference. Blagoveshchensk: Far-Eastern State Agrarian University, p. 108-109.

Earle, C. J., 2011: Larix (larch) description. The Gymnosperm Database.

Fries, A., Ericsson, T., 2006: Estimating Genetic Parameters for Wood Density of Scots Pine (Pinus sylvestris L.). Silvae Genetica, 55:84-92.

Givnish, T. J., 2002: Adaptive significance of evergreen vs. deciduous leaves: solving the triple paradox. Silva Fennica, 36:703-743.
Grigoriev, I. O., 2009: System cars for logging works. Tree.ru, p. 44-47.

Kang, K.-Y., Zhang, S.Y., Mansfield, S.D., 2004: The Effects of Initial Spacing on Wood Density, Fibre and Pulp Properties in Jack Pine (Pinus banksiana L.). Holzforschung, 58:455-468.

Kostenko, N. A., 2012: Influence of wood density on the performance of logging systems of machines used in the Amur region. Bulletin of Krasnoyarsk State Agrarian University, 2:187-191.

Kozlov, V. A., Kisternaya, M. V., Neronova, J. A., 2009: Influence of forest management on density and chemical composition of wood of Scots pine. Lesn. Journ. Bulletin of higher educational institutions, 6:7-13.

Moser, W. K., Hansen, M. H., Gormanson, D., Gilbert, J. H., Wrobel, A., Emery, M. R., Dockry, M. J., 2015: Paper Birch (Wiigwaas) of the Lake States, 19802010. USA: Department of Agriculture, Forest Service, Northern Research Station, $37 \mathrm{p}$.

Peltola, H., Gort, J., Pulkkinen, P., Gerendiain, A. Z., Karppinen, J., Ikonen, V.-P., 2009: Differences in Growth and Wood Density Traits in Scots Pine (Pinus sylvestris L.) Genetic Entries Grown at Different Spacing and Sites. Silva Fennica, 43:339-354.

Romanova, N. A., 2017: Determination of the dependence of the productivity of the chainsaw on the density of pine wood with a multifactorial experiment. "Agro-industrial complex: problems and prospects of development": International thematic scientific and practical conference. Blagoveshchensk: Far-Eastern State Agrarian University, p. 259-264.

Romanova, N. A., Baranov, A. V., 2016: Multifactorial experiment to determine system performance of forestry machines. Systems. Methods. Technologies. Bratsk: Bratsk State University, 2:133-137.

Romanova, N. A., Sorvina, L. V., 2017: The influence of the area of birch wood growth on the productivity of the chainsaw in its harvesting in the Amur region. Problems and prospects of development of the agroindustrial complex of Russia. Materials of all-Russian scientific and practical conference. Blagoveshchensk: Far-Eastern State Agrarian University, p. 64-67.

Skurikhin, V. I., Korpachev, V. P., 2004:Technology and equipment of timber industry. Technique and technology of logging operations in the harvesting of logs. Krasnoyarsk: SibSTU, 186 p.

Stanturf, J. A., Madsen, P., 2004: Restoration of Boreal and Temperate Forests. USA, Boca Raton, $600 \mathrm{p}$.

Tyukavina, O. N., Klevtsov, D. N., Drozdov, I. I., Melekhov, V. I., 2017: Wood density of Scots pine in different growing conditions. Lesnoy zhurnal, 6:56-64.

Ugolev, B. N., 2002: Wood studies with the basics of forest commodity: a Textbook for forestry universities. Ed. $3^{\text {rd }}$, revised and enlarged edition. M.: Moscow State University of Forest, 340 p. 
Yaborov, V. T., 2005: Bases of introduction of forestry and organization of forest management. Blagoveshchensk: Far-Eastern State Agrarian University, 284 p.
Wang, T., Aitken, S. N., Rozenberg, P., Millie, F., 2000: Selection for Improved Growth and Wood Density in Lodgepole Pine: Effects on Radial Patterns of Wood Variation. Wood and Fiber Science, 32:391-403.

Zaki, M. J., Meira, W. Jr., 2014: Data Mining and Analysis: Fundamental Concepts and Algorithms. Cambridge, $593 \mathrm{p}$. 